\title{
Perspective
}

PERSPECTIVE Actualité en histoire de l'art

Comptes rendus | 2010

\section{Andrew Leach, What is Architectural History?, Cambridge/Malden, Polity, 2010}

\section{Zeynep Çelik}

\section{OpenEdition}

Journals

Édition électronique

URL : http://journals.openedition.org/perspective/2647

DOI : 10.4000/perspective. 2647

ISSN : 2269-7721

Éditeur

Institut national d'histoire de l'art

Référence électronique

Zeynep Çelik, «Andrew Leach, What is Architectural History?, Cambridge/Malden, Polity, 2010 »,

Perspective [En ligne], Comptes rendus, mis en ligne le 01 août 2013, consulté le 01 octobre 2020

URL : http://journals.openedition.org/perspective/2647 ; DOI : https://doi.org/10.4000/perspective. 2647

Ce document a été généré automatiquement le 1 octobre 2020. 


\section{Andrew Leach, What is Architectural History?, Cambridge/Malden, Polity, 2010}

Zeynep Çelik

\section{RÉFÉRENCE}

Andrew Leach, What is Architectural History?, Cambridge/Malden, Polity, 2010. 
Dans cette introduction concise à l'historiographie de l'architecture, Leach rend accessible à un large lectorat la question complexe de la connaissance historique en architecture. Il démultiplie les angles d'approche de la discipline, considère l'évolution des approches théoriques et méthodologiques et les ANDREW LEACH

\section{What is} Architectural History? resitue dans leurs contextes. Il en révèle toute la richesse, mettant en lumière aussi bien les stratégies et les ambigüités de ce champ de recherche que ses échanges avec d'autres disciplines, aussi bien sa négociation de polarités (culture d'élite/ culture populaire, le général/le particulier) que sa relation à la pratique architecturale. L'analyse qu'il propose de textes clés soulève inévitablement la question: quelle est la signification de l'histoire de l'architecture aujourd'hui ?

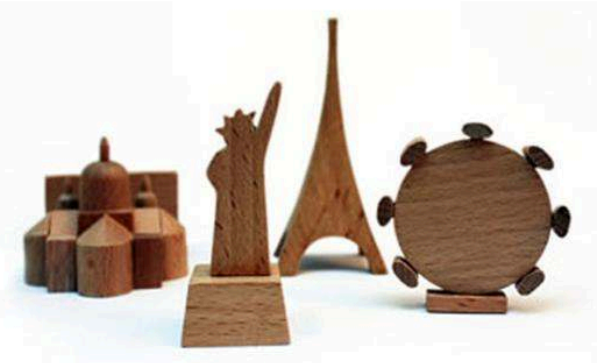

